\title{
Erratum to: Radiation-induced miR-208a increases the proliferation and radioresistance by targeting p21 in human lung cancer cells
}

Yiting Tang ${ }^{1+}$, Yayun Cui ${ }^{2+}$, Zengpeng $\mathrm{Li}^{3+}$, Zhuqing Jiao ${ }^{4}$, Yong Zhang ${ }^{5}$, Yan He ${ }^{6}$, Guangxia Chen ${ }^{7}$, Qunyan Zhou ${ }^{8}$, Wenjie Wang ${ }^{6}$, Xifa Zhou', Judong Luo ${ }^{1 *}$ and Shuyu Zhang ${ }^{6 *}$

Unfortunately, the original version of this article [1] contained an error. The name of one of the authors was included incorrectly and it read "Guangxia Cheng" instead of "Guangxia Chen".

The name has been updated in the original article and is also correctly included in full in this erratum.

\begin{abstract}
Author details
'Department of Radiation Oncology, Changzhou Cancer Hospital, Soochow University, Changzhou 213001, China. ${ }^{2}$ Department of Radiation Oncology, Anhui Provincial Hospital, Hefei 213001, China. ${ }^{3}$ State Key Laboratory Breeding Base of Marine Genetic Resources, Third Institute of Oceanography, State Oceanic Administration, Xiamen 361005, China. ${ }^{4}$ Department School of Information Science and Engineering, Changzhou University, Changzhou 213164, China. ${ }^{5}$ Department of Radiation Oncology, Shandong Cancer Hospital and Institute, Shandong University, Jinan 250117, China. ${ }^{6}$ School of Radiation Medicine and Protection and Collaborative Innovation Center of Radiation Medicine of Jiangsu Higher Education Institutions, Soochow University, Suzhou 215123, China. ${ }^{7}$ Department of Gastroenterology, First People's Hospital of Xuzhou, Xuzhou 221002, China. ${ }^{8}$ Department of Gastroenterology, Wuxi People's Hospital Affiliated to Nanjing Medical University, Wuxi 214002, China.
\end{abstract}

Received: 26 January 2016 Accepted: 26 January 2016

Published: 28 January 2016

\section{References}

1. Tang Y, Cui Y, Li Z, Jiao Z, Zhang Y, He Y, et al. Radiation-induced miR-208a increases the proliferation and radioresistance by targeting p21 in human lung cancer cells. J Exp Clin Cancer Res. 2016;35:7.

\footnotetext{
*Correspondence: judongluo@163.com; zhang.shuyu@hotmail.com ${ }^{\dagger}$ Equal contributors

'Department of Radiation Oncology, Changzhou Cancer Hospital, Soochow University, Changzhou 213001, China

${ }^{6} \mathrm{~S}$ chool of Radiation Medicine and Protection and Collaborative Innovation Center of Radiation Medicine of Jiangsu Higher Education Institutions, Soochow University, Suzhou 215123, China

Full list of author information is available at the end of the article
}

\footnotetext{
Submit your next manuscript to BioMed Central and we will help you at every step:

- We accept pre-submission inquiries

- Our selector tool helps you to find the most relevant journal

- We provide round the clock customer support

- Convenient online submission

- Thorough peer review

- Inclusion in PubMed and all major indexing services

- Maximum visibility for your research
}

Submit your manuscript at

www.biomedcentral.com/submit 